\title{
A woman with a history of colorectal carcinoma presenting with an abdominal mass
}

\author{
Robert J Schipper, Laurents P Stassen, Marjolein L Smidt, Rutger M Schols
}

Department of Surgery, Maastricht University Medical Center, Maastricht, The Netherlands

\section{Correspondence to}

Rutger M Schols, rutgermschols@hotmail.com

\section{DESCRIPTION}

A 72-year-old woman presented with an abdominal pain in the left lower quadrant, fever $\left(39^{\circ} \mathrm{C}\right)$ and nausea. In 2010 she underwent a laparoscopic right hemicolectomy for a pT3N0 adenocarcinoma. The clinical examination was not suggestive for an acute abdomen. Infection parameters were elevated (C reactive protein $116 \mathrm{mg} / \mathrm{L}$; reference value $<10 \mathrm{mg} / \mathrm{L}$ ). Differential diagnosis was internal herniation or diverticulitis.

A CT scan (figure 1) revealed an abdominal mass in the mesentery of the small intestine suspicious for recurrence of colonic adenocarcinoma. The mass was surrounded by multiple pathologically enlarged lymph nodes; there were no signs of distant metastases in liver or lungs. An elective, explorative laparotomy was performed. A tumour, measuring $7 \mathrm{~cm}$, was detected in the mesentery of the small intestine and resected radically (figure 2).

Histopathology showed a mesenteric (or deep) fibromatosis with maximum diameter of $9 \mathrm{~cm}$, radical resection margins and 14 benign lymph nodes. Molecular examination detected a mutation

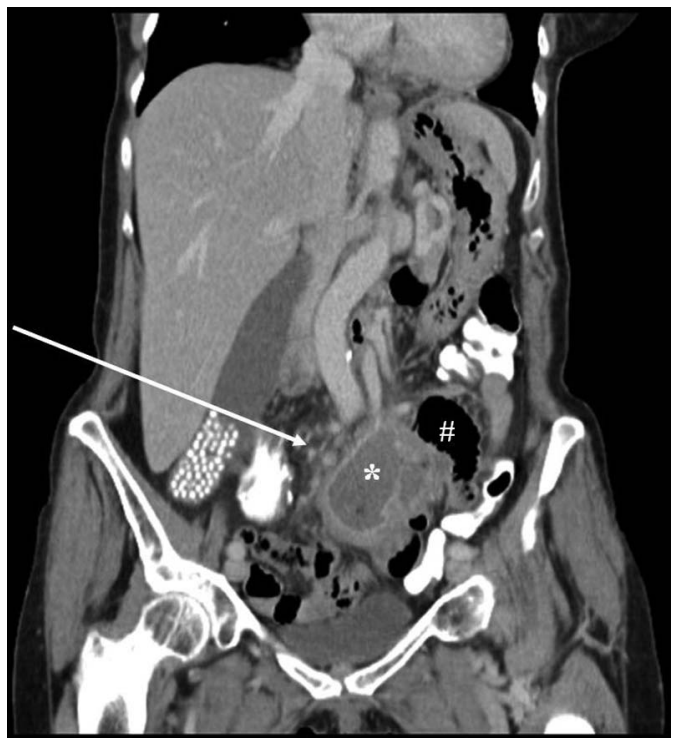

Figure 1 Coronal view of CT of the abdomen, portal venous phase, showing known cholecystolithiasis and an unsharp delineated hypodense mass $\left({ }^{*}\right)$ - diameter of $8 \mathrm{~cm}$-with suggestion of infiltration of surrounding fat. An intra-abdominal abscess is unlikely. The mass is probably primarily located in the mesentery of the small intestine; there is a close relation with or even invasion of the small intestine (\#). Multiple pathologically enlarged lymph nodes are present (indicated by the arrow). Furthermore there are no signs of distance metastasis. Image is suspicious for recurrence of colonic adenocarcinoma.

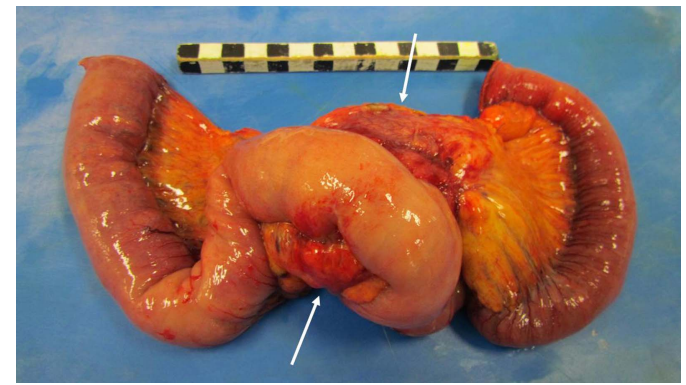

Figure 2 Resected segment of the small intestine and mesenteric tumour (indicated by the arrows).

of the $\beta$-catenine gene (codon $41 \mathrm{~A}$ of exon 3 ), supporting the diagnosis of deep fibromatosis. After multidisciplinary consultation no adjuvant therapy was given.

Mesenteric fibromatosis, a desmoid tumour, concerns an infrequent diagnosis. Desmoid tumours are sometimes associated with familial adenomatous polyposis, which is caused by a mutation in the APC gene. A sporadic mutation in exon 3 of the $\beta$-catenine gene is mostly causative for desmoid tumours. Three codon mutations of this exon are identified: $41 \mathrm{~A}, 45 \mathrm{~F}$ and $45 \mathrm{P}^{1}$

Desmoid tumours do not have the ability to metastasise, but often tend to recur locally despite previous radical resection. $^{2}$

Five-year recurrence-free survival is favourable in non-mutated or 41A-mutated tumours $(57 \%){ }^{1}$ This endpoint can also be calculated using a nomogram based on size, site and age: ${ }^{3} 90 \%$ in this case.

\section{Learning points}

- Mesenteric fibromatosis, or desmoid tumours, are rare but should be considered in patients with severe abdominal pain and mesenteric mass on CT scan.

- Despite radical surgical resection recurrence rates are high.

- Molecular examination and a prognostic nomogram can help predict recurrence-free survival rate, therewith guiding adjuvant treatment.

Contributors All authors wrote and reviewed the manuscript. Competing interests None.

Patient consent Obtained.

Provenance and peer review Not commissioned; externally peer reviewed. 


\section{REFERENCES}

1 Lazar AJ, Tuvin D, Hajibashi S, et al. Specific mutations in the beta-catenin gene (CTNNB1) correlate with local recurrence in sporadic desmoid tumors. Am J Pathol 2008; 173:1518-27.
2 Lewis JJ, Boland PJ, Leung DH, et al. The enigma of desmoid tumors. Ann Surg 1999;229:866-72; discussion 872-3.

3 Crago AM, Denton B, Salas $S$, et al. A prognostic nomogram for prediction of recurrence in desmoid fibromatosis. Ann Surg 2013;258:347-53.

Copyright 2013 BMJ Publishing Group. All rights reserved. For permission to reuse any of this content visit

http://group.bmj.com/group/rights-licensing/permissions.

BMJ Case Report Fellows may re-use this article for personal use and teaching without any further permission.

Become a Fellow of BMJ Case Reports today and you can:

- Submit as many cases as you like

- Enjoy fast sympathetic peer review and rapid publication of accepted articles

- Access all the published articles

- Re-use any of the published material for personal use and teaching without further permission

For information on Institutional Fellowships contact consortiasales@bmjgroup.com

Visit casereports.bmj.com for more articles like this and to become a Fellow 